\title{
IDENTIFIKASI TINGKAT PENCEMARAN PADA LAHAN PERTANIAN MENGGUNAKAN METODE KEMAGNETAN BATUAN
}

\author{
Adinda Syifa Azhari ${ }^{1, a)}$, Eleonora Agustine ${ }^{2, b)}$, Dini Fitriani ${ }^{3, c)}$ \\ Departemen Geofisika, Fakultas Matematika dan ilmu pengetahuan alam, Universitas Padjadjaran, \\ Jl. Bandung-Jatinangor km. 21, Jatinangor 45363, Indonesia. \\ Email : syifaazhari07@gmail.com ${ }^{\text {a) }}$, leo@geophys.unpad.ac.id ${ }^{\text {b) }}$,dini@geophys.unpad.ac.id ${ }^{\text {c) }}$
}

\begin{abstract}
Abstrak
Setiap kegiatan industri mempunyai potensi untuk membuat pencemaran pada lahan pertanian, terutama industri yang bergerak dibidang tekstil dimana hasil limbahnya dibuang ke sungai yang membuat lingkungan sekitar menjadi tercemar,namun dalam penelitian kali ini objek yang akan di teliti adalah tanah di lahan pertanian yang berada di sekitar pabrik tekstil. Penelitian ini bertujuan untuk mendapatkan informasi mengenai tingkat pencemaran tanah pada lahan pertanian yang diakibatkan oleh buangan limbah pabrik tekstil yang berlokasi di Bandung. Penelitian Sampel tanah yang diambil pada dua area yang berbeda, yaitu daerah yang dekat dengan sumber pencemaran (a) dan daerah yang jauh dari sumber pencemaran (b). Setelah melakukan pengukuran diperoleh data sebagai berikut: $\mathrm{PH}(\mathrm{a})=7,8, \mathrm{PH}(\mathrm{b})=7,1$, TDS dan EC (a) = 0,161 - 0,313 dan 0,34 - 0,627, TDS dan EC (b) = 0,06- 0,206 dan 0,127 - 0,419, $\chi_{\mathrm{fd}} \%$ (a) $=0,66-2,4 \%, \chi_{\mathrm{fd}} \%(\mathrm{~b})=3,26-3,76 \%$. Data tersebut menunjukkan tingkat pencemaran lahan pada lokasi a dengan karakteristik PH (>), nilai TDS dan EC (>>) dan $\chi_{\mathrm{fd}} \%(<<)$ atau dengan spesifikasi tanah relatif bersifat basa dengan bulir yang cukup kasar serta mengandung konsentrasi garam yang tinggi.
\end{abstract}

Kata kunci: Pabrik tekstil, pencemaran, suseptibilitas, tanah.

\begin{abstract}
Every industrial activity has the potential to make pollution on agricultural land, in general waste out of that factory is dumped directly into the river, where the waste can be a waste of toxic for the environment. The study aims to get information from the soil sample has been meticulous about the level of pollution in farming caused by waste disposal a textile mill which is located in Bandung. The experiment at the different places, there is the area which located closer by pollution source (a) and area which far from pollution source (b). After we've done the measurement, we got some data, there are $\mathrm{PH}(\mathrm{a})=7,8, \mathrm{PH}(\mathrm{b})=7,1$, TDS dan $\mathrm{EC}$ (a) $=0,161-0,313$ dan $0,34-0,627$, TDS dan EC (b) $=0,06-0,206$ dan 0,127 - 0,419, $\chi_{\mathrm{fd}} \%$ (a) $=0,66-2,4 \%, \chi_{\mathrm{fd}} \%$ (b) $=3,26-3,76$ $\%$. That data is shown the pollution of the soil at the place, it is area (a), which specification are PH (>>), TDS and EC $(\gg>)$ and $\chi_{\mathrm{fd}} \%(<<)$, it means the soil is alkali with big grain and has high salt concentration.
\end{abstract}

Keywords: Industrial textiles, pollution, land. 


\section{PENDAHULUAN}

Dengan meningkatnya pembangunan nasional dan peningkatan industrialisasi, maka akan menghasilkan limbah dan polusi. limbah yang dihasilkan dari kegiatan industri dapat membahayakan bagi daerah di sekitar lahan pertanian. Dampak yang terjadi akibat kegiatan industri pada lahan pertanian selain mengganggu keseimbangan ekosistem juga membuat unsur hara yang terkandung dalam tanah akan berubah dan membuat tanah memiliki potensi tercemar, sehingga mengganggu kualitas dari hasil pertanian tersebut.Pada penelitian ini, metode yang digunakan untuk mengidentifikasi sifat magnetik lahan pertanian adalah metode kemagnetan batuan. Kajian kemagnetan batuan ini dilakukan karena dapat mengidentifikasi sifat magnetik dari suatu sampel yang terkena pencemaran, dalam penelitian ini yaitu pencemaran tanah akibat kegiatan industri tekstil. Parameter yang akan diukur yaitu suseptibilitas magnetik, dan juga pengukuran tingkat salinitas tanah sampel sebagai data pelengkap dengan menggunakan Electrical Conductivity (EC-meter) serta $\mathrm{PH}$ meter.

\section{Metode kemagnetan batuan}

Metode kemagnetan batuan adalah salah satu metode geofisika yang digunakan untuk mengidentifikasi mineral magnetik dari suatu batuan dengan memanfaatkan sifat kemagnetan terhadap parameter fisis magnetik dari sampel yang diteliti. Pengukuran parameter fisis ini dapat berupa pengukuran suseptibilitas magnetik, remanensi magnetik, anisotropi suseptibilitas magnetik, dan kurva histeresis. Pengukuranpengukuran parameter fisis ini dapat digunakan untuk mengidentifikasi karakteristik mineral magnetik yang terkandung dalam sampel. Metode kemagnetan batuan dapat pula diaplikasikan untuk studi mineral magnetik dari tanah, debu, ataupun lumpur. Dengan berkembangnya kajian kemagnetan batuan,partikulat yang terserap oleh tanaman dapat di deteksi [3]. Salah satunya dengan menggunakan tanah sebagai bahan uji. Dengan menggunakan alat Bartington $M S 2 B$, partikulat yang terserap tersebut dapat di deteksi dan mengetahui jenis magnetik berdasarkan nilai suseptibilitas magnetik. Hal ini berguna untuk menginformasikan tingkat pencemaran dan jenis magnetik tanah pada lokasi tersebut.

\section{Electrical Conductivity (EC)}

EC meter digunakan untuk mengetahui kualitas larutan nutrisi yang terdapat pada tanah. Semakin tinggi nilai EC suatu larutan hara maka semakin besar arus listrik yang dapat dihantarkan. Adapun nilai $\mathrm{pH}$ mempengaruhi ketersediaan unsur hara[1]. Salinitas adalah tingkat kepekatan suatu garam atau kadar garam terlarut dalam air. Salinitas juga dapat mengacu pada kandungan garam dalam tanah. Salinitas merupakan salah satu parameter dalam mengidentifikasi tingkat kesuburan suatu tanah atau tanaman. Semakin tinggi nilai salinitas maka salah satu akibatnya terjadi degradasi lahan. Oleh karena itu,salinitas merupakan ancaman bagi produktivitas pertanian.

Pencemaran industri dan kendaraan bermotor serta bencana alam yang terjadi seperti tsunami juga dapat mengakibatkan lahan pertanian menjadi salin atau mengalami peningkatan kadar garam yang tinggi. Salinitas yang identik dengan peningkatan kandungan garam, merupakan gambaran banyaknya konsentrasi ion garam yang terdapat dalam media baik tanah maupun air. Salinitas dalam suatu media dapat dinyatakan melalui konsentrasi dan konduktivitas. Konsentrasi dapat diukur dengan menggunakan TDS (Total Dissolved Solid), sedangkan konduktivitas dapat diukur dengan menggunakan EC-meter (Electrical Conductivity) dalam satuan deciSiemens per meter $(\mathrm{dS} / \mathrm{m})$ atau milimhos per centimeter $(\mathrm{mmhos} / \mathrm{cm})$. Pengukuran Electrical Conductivity (EC) merupakan pengukuran tingkat kepekatan unsur hara dalam larutan. Semakin pekat larutan maka semakin besar pengantaran aliran listrik dari kation(+) dan anion (-) ke anode dan katode EC meter, sehingga EC semakin tinggi. EC meter digunakan untuk mengukur konsentrasi hara yaitu mengukur kelancaran pengantaran listrik antara katoda positif dan anoda negatif. EC larutan hara yang tinggi menyebabkan umur panen lebih singkat dan juga berpengaruh pada ketahanan terhadap serangan penyakit tanaman. Tetapi, EC yang terlalu tinggi melebihi ambang batas akan merusak tanaman [5]. 


\section{METODE PENELITIAN}

Pada penelitian ini, lokasi penelitian berada di dua lokasi yang berbeda yaitu lokasi yang dekat dengan pabrik dan lokasi yang jauh dengan pabrik.

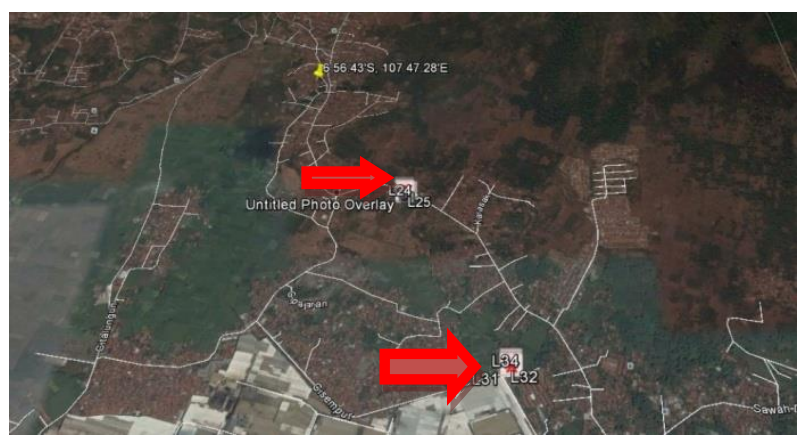

GAMBAR 1 lokasi pengambilan sampel

Parameter yang akan diukur yaitu suseptibilitas magnetik, dan juga pengukuran tingkat salinitas tanah sampel sebagai data pelengkap dengan menggunakan Electrical Conductivity (EC-meter) serta PH meter. Pengambilan sampel dilakukan di dua lokasi berbeda yaitu di daerah yang jauh dengan pabrik tekstil dan daerah yang dekat dengan pabrik tekstil yang bertujuan untuk mengetahui perbedaannya. Dalam melakukan penelitian dengan metode ini, penelitian terdiri dari beberapa tahapan yaitu, persiapan dan pelaksanaan pengambilan sampel, pencuplikan dan preparasi sampel, pengukuran sampel, dan analisis hasil serta penyusunan penulisan. Tahap pertama dalam penelitian ini adalah persiapan dan pelaksanaan pengambilan sampel. Sampel yang akan diteliti yaitu sampel tanah yang diambil pada permukaan dengan panjang lintasan 100 meter, dan pengambilan sampel setiap 20 meter.

Setelah pengambilan sampel selesai dan sampel tanah tersebut dimasukan kedalam plastik zip, serta di plot lokasi penelitian dengan menggunakan GPS, selanjutnya adalah melakukan tahap yang kedua yaitu pencuplikan dengan memasukkan sampel pada holder dengn padat. Pada penelitian di dua lokasi ini terdapat 10 titik pengambilan sampel yang berarti ada 10 holder sampel. Setelah sampel dimasukkan ke dalam holder, selanjutnya adalah preparasi sampel dengan memberikan penamaan pada sampel sesuai dengan kode posisi titik sampel pada lintasan. Dan sisa sampel yang tidak dimasukkan kedalam holder, dimasukkan kedalam aqua gelas untuk di teliti nilai pH, TDS dan EC. Sampel sisa yang dimasukkan kedalam aqua gelas di beri cairan aquabides dan diendapkan selama 12 jam sebelum dilakukan pengukuran.

Pengukuran menggunakan pH meter, TDS (Total Dissolved Solid), dan Electrical Conductivity (ECmeter) dilakukan di rumah. Pengukuran dengan TDS meter yaitu :

1. Pertama alat dikalibrasi dengan cara mencelupkan alat kedalam air dengan $\mathrm{pH}$ normal lalu di celupkan pada air dengan $\mathrm{pH}$ asam,setelah itu di celupkan kembali kedalam air dengan $\mathrm{pH}$ normal selanjutnya dicelupkan kedalam air dengan $\mathrm{pH}$ basa lalu di celupkan kembali ke air dengan $\mathrm{pH}$ normal.

2. Setelah alat dikalibrasi selanjutnya adalah mulai mengukur sampel dengan $3 x$ pengukuran, pada alat yang kami gunakan bisa mengukur TDS dan EC secara bergantian dengan alat yang sama. Untuk pengukuran TDS, sampel di kocok terlebih dahulu lalu alat yang telah dikalibrasi di masukan kedalam sampel. Setelah itu, tekan tombol shift untuk memindahkan ke pengukuran EC, untuk satu sampel pengukuran dilakukan sebanyak $3 \mathrm{x}$ dan setiap perpindahan pengukuran, alat di celupkan ke dalam cairan aquabides, yang bertujuan untuk membersihkan alat sehingga tidak terkontaminasi dengan sampel yang lain.

3. Alat ini dapat mengukur secara otomatis, ketika di celupkan kedalam sampel. Untuk pembacaan nilai yang terukur diamkan selama 2 hingga 3 menit sampai nilai yang muncul. 


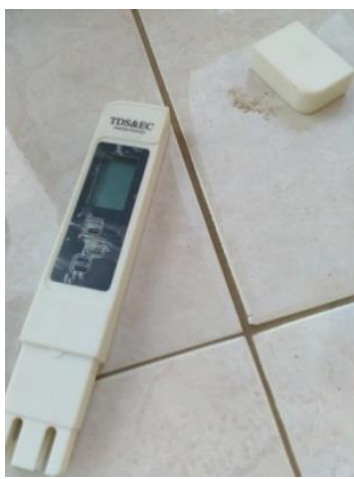

(a)

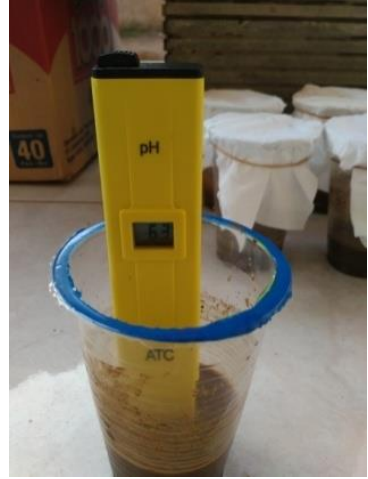

(b)

GAMBAR 2 (a) Alat TDS dan EC meter, (b) Alat ph meter

pH meter merupakan alat yang digunakan untuk mengetahui derajat keasaman atau kebasaan suatu tanah, maupun air. Pengukuran $\mathrm{pH}$ meter:

1. Pertama bersihkan alat dengan cara mencelupkan alat ke dalam cairan aquabides, agar alat tidak terkontaminasi oleh sampel.

2. Tancapkan alat pada sampel, pengukuran dilakukan sebanyak 3x. Setiap selesai pengukuran, alat di celupkan kembali kedalam aquabides agar alat bersih dari sampel. Sebelum pengukuran, sampel dikocok terlebih dahulu.

3. Untuk pembacaan,tunggu sampai nilai yang muncul pada alat bernilai stabil. Jika nilai yang keluar kurang dari 7 artinya sampel tersebut bersifat asam, dan jika nilai yang keluar bernilai lebih dari 7 artinya sampel tersebut bersifat basa, sedangkan jika nilai yang keluar adalah 7 maka sampel tersebut bersifat normal.

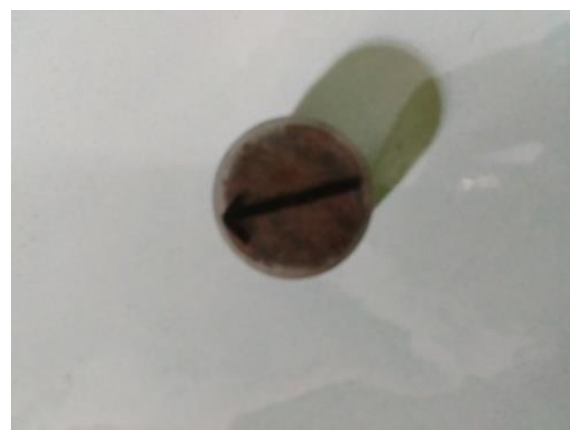

(a)

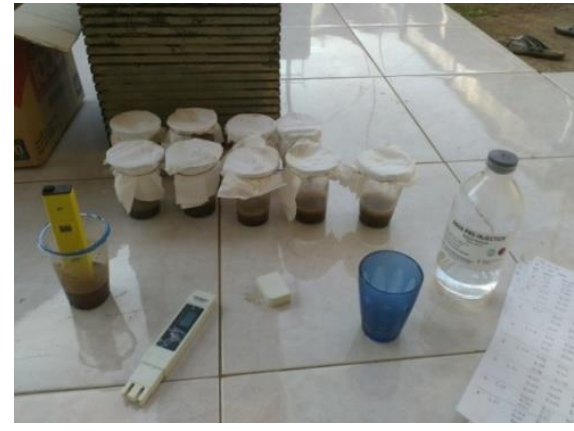

(b)

GAMBAR 3 (a)sampel yang dimasukkan ke holder, (b) sampel yang diendapkan dengan aquabides.

Sampel yang telah dimasukkan kedalam holder dan dipreparasi kemudian dilakukan pengukuran di Laboratorium Basic Science Centre (BSC - A) ITB. Pengukuran yang dilakukan yaitu suseptibilitas magnetik dengan menggunakan alat Bartington MS2B yang beroperasi pada frekuensi $460 \mathrm{~Hz}$ (frekuensi rendah) dan $4600 \mathrm{~Hz}$ (frekuensi tinggi). Kemudian sisa sampel yang diendapkan di dalam aqua gelas di lakukan pengukuran sebanyak 3x setiap 12 jam sekali, untuk melihat perbedaannya [2]. 


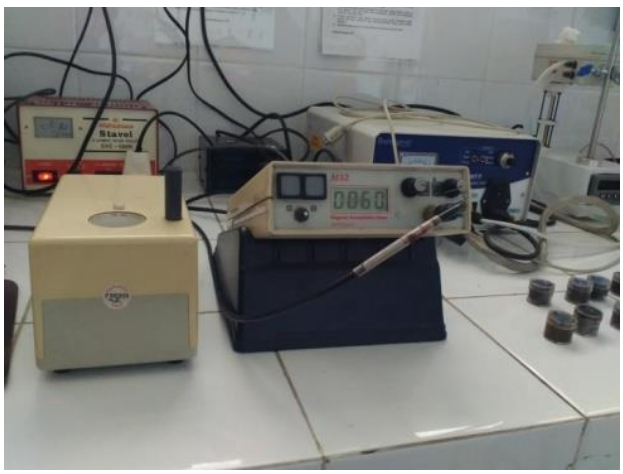

GAMBAR 4 Alat Bartington MS2B

\section{HASIL DAN PEMBAHASAN}

Nilai TDS, EC, dan PH pada lokasi yang dekat dengan pabrik memiliki nilai yang lebih besar jika dibandingkan dengan lokasi yang jauh dengan pabrik. Nilai EC pada lokasi yang dekat dengan pabrik memiliki kepekatan unsur hara yang lebih tinggi jika dibandingkan dengan sampel yang berada di lokasi yang jauh dengan pabrik. Nilai PH pada lokasi sampel yang dekat dengan pabrik memiliki nilai PH basa namun semakin lama sampel diendapkan maka nilai PH yang didapatkan berubah menjadi semakin asam. Sedangkan pada lokasi yang jauh dengan pabrik didapatkan nilai awal PH mendekati normal namun semakin lama sampel diendapkan maka PH berubah menjadi semakin asam.

Salinitas kepekatan kandungan garam pada tanah dapat dinyatakan melalui konsentrasi, yang diukur menggunakan TDS (Total Dissolved Solid), dari data di atas nilai TDS semakin lama nilai nya semakin bertambah tinggi, yang berarti bahwa pada sampel didapatkan konsentrasi kandungan garam didalam tanah pada lokasi tersebut bila diendapkan semakin lama hasilnya adalah semakin tinggi. Nilai TDS dilokasi yang dekat dengan pabrik nilai nya lebih tinggi dibandingkan dengan nilai TDS yang lokasi sampel nya jauh dengan pabrik. Berarti hal tersebut menunjukkan bahwa dilokasi yang dekat dengan pabrik memiliki nilai konsentrasi kandungan garam yang lebih tinggi dibandingkan dengan lokasi yang jauh dengan pabrik.

\section{Hasil Pengukuran Suseptibilitas Magnetik}

Hasil pengukuran suseptibilitas magnetik menggunakan alat Bartington MS2B di dapatkan nilai suseptibilitas magnetik di daerah yang jauh dengan lokasi pabrik nilai nya lebih tinggi dibandingkan dengan lokasi yang dekat dengan pabrik. Jika nilai $\chi_{\mathrm{fd}}(\%)>3 \%$ maka hal tersebut menunjukkan bahwa bulir pada tanah tersebut halus. Biasanya daerah yang berpotensi tercemar memiliki ukuran bulir yang halus. Didaerah yang dekat dengan pabrik nilai suseptibilitas $\left(\chi_{l f}\right)$ lebih rendah kemungkinan tanah yang dekat pabrik mengalami penurunan nilai suseptibilitas $\left(\chi_{f f}\right)$ akibat menghilangnya kandungan mineral yang disebabkan dari kontaminasi oleh pabrik,yang membuat karakteristik tanah menjadi berubah dan kehilangan unsur hara yang ditunjukkan pada GAMBAR 5 dibawah ini : 


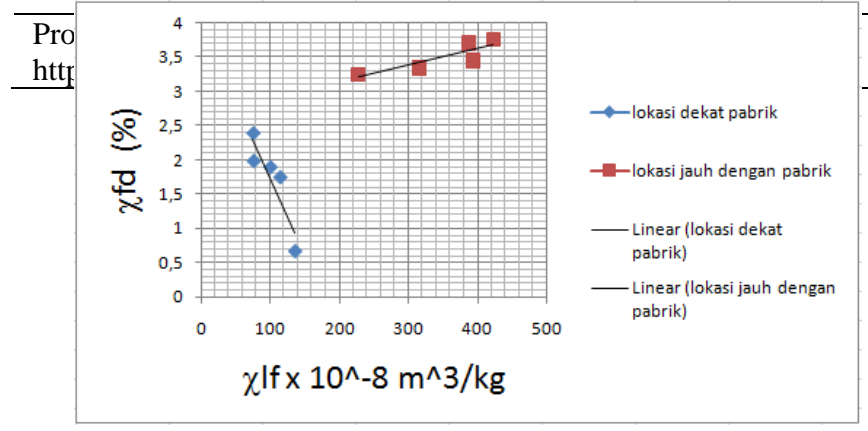

(a)

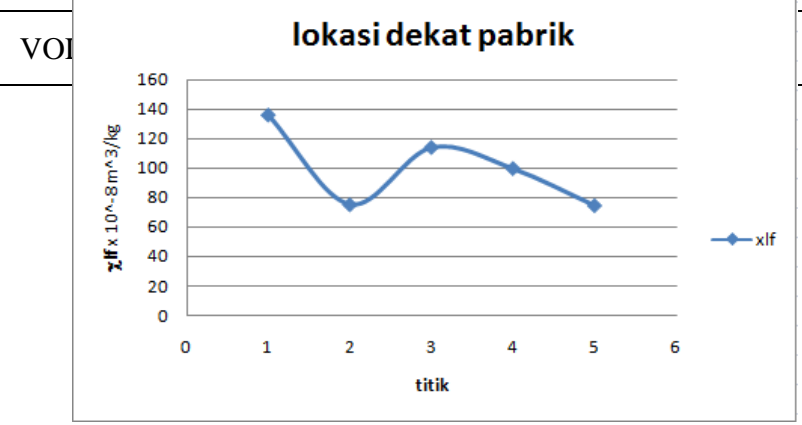

(b)

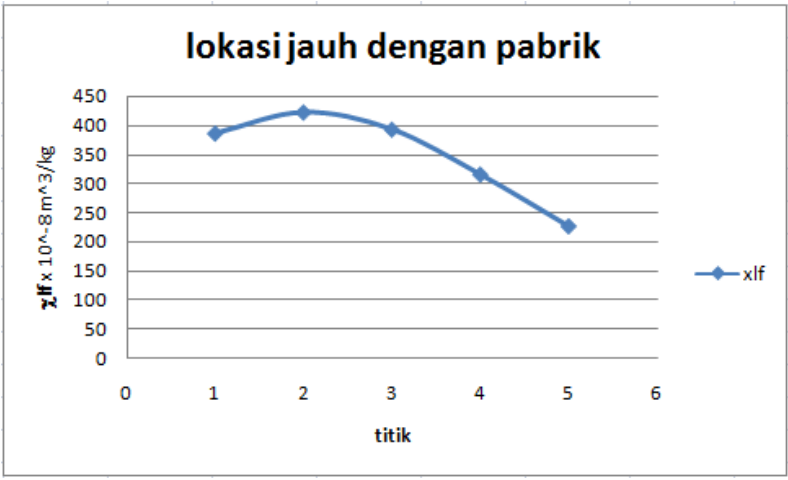

(c)

GAMBAR 5 (a). nilai $\chi_{\mathrm{fd}}$ terhadap nilai $\chi_{\mathrm{If}}$ pada kedua lokasi penelitian, (b). nilai suseptibilitas low frequency ( $\left.\chi_{l f}\right)$ pada lokasi yang dekat pabrik, (c). nilai suseptibilitas low frequency $\left(\chi_{l f}\right)$ pada lokasi yang jauh dengan pabrik

Pada GAMBAR 5 bagian (a) diatas menunjukkan bahwa nilai suseptibilitas magnetik low frequency ( $\chi_{\mathrm{lf}}$ )berbanding terbalik dengan nilai $\left(\chi_{\mathrm{fd}}\right.$, yang menunjukkan bahwa semakin halus bulir magnetik maka nilai suseptibilitas magnetik semakin menurun, tanah yang berpotensi tercemar memiliki korelasi negatif, seperti penelitian yang pernah dilakukan oleh Lu Sheng Gao dkk (2008) pada penelitian nya didaerah industri menunjukkan bahwa grafik korelasi daerah polusi akibat kegiatan industri menunjukkan korelasi negatif yang ditunjukkan pada GAMBAR 6 [4].

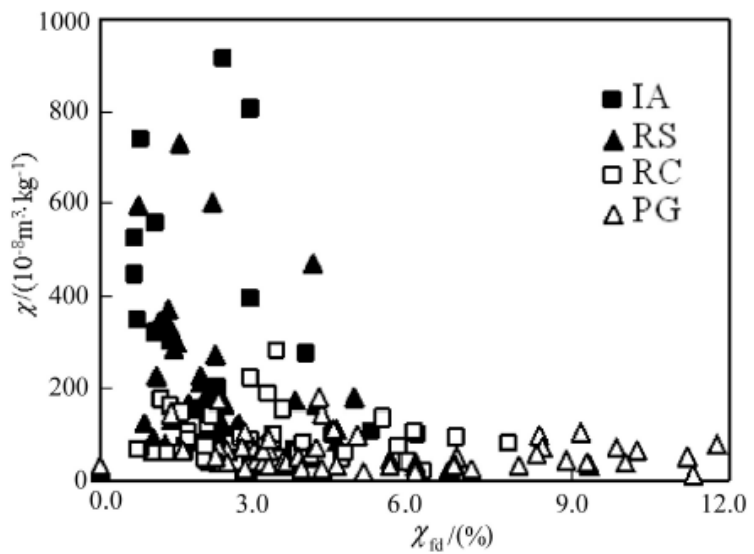

GAMBAR 6 Grafik korelasi $\chi l f$ terhadap $\chi f d$ (Gao,dkk chinese journal of geophysics 2008)

\section{SIMPULAN}

Dari hasil penelitian yang telah dilakukan dapat disimpulkan bahwa:

1. Lokasi yang dekat dengan pabrik memiliki nilai TDS dan EC yang lebih tinggi dibandingkan dengan lokasi yang jauh dengan pabrik. Hal tersebut menunjukkan bahwa pada lokasi yang dekat dengan pabrik berdasarkan pengukuran menggunakan alat TDS memiliki konsentrasi kepekatan kandungan garam dalam tanah yang tinggi.

2. Hasil pengukuran Electrical Conductivity (EC), didapatkan hasil yang semakin tinggi, hal tersebut menunjukkan bahwa semakin pekat larutan maka semakin besar pengantaran aliran listrik pada tanah sehingga hasilnya nilai EC semakin tinggi.

3. Hasil pengukuran PH di dapatkan nilai nya semakin hari semakin asam hal tersebut menunjukkan bahwa ion $\mathrm{H}+$ yang bereaksi sehingga sampel nya semakin asam. 
4. Pada pengukuran pertama lokasi yang dekat dengan pabrik memiliki PH 7,8 (basa) hal tersebut menunjukkan bahwa tempat tersebut berpotensi tercemar dan mencemari tanaman di sekitarnya. Sedangkan nilai ph di lokasi yang jauh dengan pabrik memiliki nilai ph awal yang normal sehingga lokasi tersebut tidak berpotensi tercemar.

5. Hasil pengukuran suseptibilitas magnetik menggunakan alat Bartington MS2B di dapatkan nilai suseptibilitas di daerah yang jauh dengan lokasi pabrik nilai nya lebih tinggi dibandingkan dengan lokasi yang dekat dengan pabrik. Jika nilai $\chi_{\mathrm{fd}}(\%)>3 \%$ maka hal tersebut menunjukkan bahwa bulir pada tanah tersebut halus. Biasanya daerah yang berpotensi tercemar memiliki ukuran bulir yang halus. Didaerah yang dekat dengan pabrik nilai suseptibilitas $\left(\chi_{l f}\right)$ lebih rendah kemungkinan tanah yang dekat pabrik mengalami penurunan nilai suseptibilitas $\left(\chi_{l f}\right)$ akibat menghilangnya kandungan mineral yang disebabkan dari kontaminasi oleh pabrik,yang membuat karakteristik tanah menjadi berubah dan kehilangan unsur hara. Selain itu,nilai suseptibilitas $\chi_{\text {lf }}$ berbanding terbalik dengan nilai $\chi_{\mathrm{fd}}$, yang menunjukkan bahwa semakin halus bulir magnetik maka nilai suseptibilitas semakin menurun.

\section{UCAPAN TERIMAKASIH}

Terima kasih kepada pak Satria Bijaksana yang telah memberikan izin untuk menggunakan peralatan laboratorium kemagnetan batuan di lab ITB, dan bu Eleonora Agustine serta bu Dini fitriani yang selalu membimbing penelitian ini. Serta rekan - rekan Geofisika UNPAD angkatan 2013 yang selalu membantu dalam setiap penelitian.

\section{REFERENSI}

[1] Agustine, Eleonora. 2015. Kajian Suseptibilitas Magnetik dan Konduktivitas Listrik Pada Tanah Vulkanik Yang Terpapar Pestisida Organochlorine. Disertasi tidak dipublikasi. Bandung: Institut Teknologi Bandung

[2] Dearing, J. 1999. Environmental Magnetic Susceptibility Using the Bartington MS2 System.Published by Chi Publishing. England

[3] Evans, M.E. dan Heller, F. 2003. Environmental Magnetism Principles and Applications of Enviromagnetics. Elsevier Science. USA

[4] Gao, Lu Sheng. dan Qing, BAI Shi. Magnetic Characterization and Magnetic Mineralogy of the Hangzhou Urban Soils and its Environmental Implications.Chinese journal of Geophysics Vol.51, No.3, 2008, pp: 549_557

[5] [5] Johnson, C.K., Doran, J. W., Duke, H. R., Wienhold, B.J., Eskridge, K.M dan Shanahan, J.F. 2001. Field-scale Electrical Conductivity Mapping For Delineating Soil Condition. Soil Science Society of America Journal. 65, 1829-1837, 2001. 
